\title{
Bacterial Diversity, Biogenic Amines and Lipids Oxidation in Traditional Dried Anchovy (Encrasicholina punctifer) during Ambient Storage
}

\author{
Ismail M. Al Bulushi ${ }^{a^{*}}$, Nejib Guizani ${ }^{\mathrm{a}}$, Mutamed Ayyash ${ }^{\mathrm{b}}$, Mohammed Al Za'ABi $^{\mathrm{c}}$, \\ Aisha Abushelaibi ${ }^{\mathrm{b}}$, Hilton C. Deeth ${ }^{\mathrm{d}}$, Zahra Al Kharousi ${ }^{\mathrm{a}}$, Fathiya Al \\ HAMAdAni $^{\mathrm{a}}$, SAlHa Al MASKARI ${ }^{\mathrm{a}}$, AND JAmila AlKAlBAnI ${ }^{\mathrm{c}}$ \\ ${ }^{\text {a }}$ Department of Food Science and Nutrition, College of Agricultural and Marine Sciences, Sultan Qaboos \\ University, P.O. Box 34, Al Khod, 123, Oman \\ b Department of Food Science, College of Food and Agriculture, United Arab Emirates, University, P.O. Box \\ 15551, Al Ain, UAE \\ ${ }^{c}$ Department of Pharmacology \& Clinical Pharmacy, College of Medicine, Sultan Qaboos, University, P.O. Box \\ 35, Al Khod 123, Oman \\ d School of Land, Crop and Food Sciences, University of Queensland, Brisbane, QLD 4072, Australia \\ ${ }^{*}$ Corresponding author \\ isab@squ.edu.om Tel: + 968 24143619; Fax: + 96824413418 \\ Received: 18 February 2019; Published online: 18 April 2020
}

\begin{abstract}
This study aimed to elucidate the effect of ambient storage $\left(23 \pm 2^{\circ} \mathrm{C}, 68 \% \mathrm{RH}\right)$ on the bacterial load and diversity, biogenic amines and lipids oxidation in traditional dried anchovy (E. punctifer) in order to evaluate its safety, quality and stability during 12 weeks of storage. Total aerobic bacteria (TAB), Staphylococcus aureus, Enterobacteriaceae (ENT), histidine decarboxylating bacteria (HDB), lysine decarboxylating bacteria (LDB) and ornithine decarboxylating bacteria (ODB) were enumerated and identified by conventional, VITEK 2 compact and sequencing of $16 \mathrm{~S}$ rRNA gene methods. Histamine, cadaverine and putrescine contents were determined by high performance liquid chromatography. Lipid oxidation was evaluated by peroxide value (PV). Total aerobic bacteria, $S$. aureus, ENT, HDB, LDB and ODB initial counts of $\log _{10} 4.9 \pm 0.85,3.7 \pm 0.57,4.2 \pm 0.05,3.7 \pm 0.72,3.9 \pm 0.40$ and $4.1 \pm$ $0.24 \mathrm{CFU} / \mathrm{g}$ respectively did not significantly change $(p>0.05)$ during 12 weeks of storage. A high bacterial diversity of 27 species belonging to 20 genera was found, with the dominance of $S$. aureus, Acinetobacter lwoffii and S. warneri and the first incidence of Psychrobacter celer, Desemzia incerta, Granulicatella elegans and Bhargavaea indica in dried fish. Initial histamine, cadaverine and putrescine contents and PV of $5.2 \pm 4.3,8.5 \pm 1.9$ and $5.8 \pm 0.6 \mathrm{mg} / 100 \mathrm{~g}$ and $0.19 \pm 0.02 \mathrm{meq} / \mathrm{kg}$ respectively did not significantly change $(p>0.05)$ during 12 weeks of storage. This study found that ambient storage at $23 \pm 2^{\circ} \mathrm{C}, 68 \% \mathrm{RH}$ for 12 weeks did not affect the bacterial load, biogenic amines and lipids, and that the dried anchovy remained microbiologically safe and of good quality.
\end{abstract}

Keywords: Traditional anchovy; Diversity; Ambient; Biogenic amines

\section{Introduction}

Traditionally, fresh anchovy is caught by trawler fishing, handled under unhygienic conditions and kept at ambient temperature for several hours, spread on sandy/clay sites and sun-dried for 35 days in open coastal areas. Pre-drying treatments such as washing and salting are not con- 


\section{Nomenclature}

TAB total aerobic bacteria

ENT Enterobacteriaceae

HDB histidine decarboxylating bacteria
LDB lysine decarboxylating bacteria

ODB ornithine decarboxylating bacteria

PV peroxide value ducted in some developing countries such as Oman.

Salting, fermenting, drying and smoking are the common fish preservation methods used in the developing countries, particularly Africa and Asia, where these methods represented 12 percent of all fish destined for human consumption in the developing countries in 2016 (Food and Agriculture Organization, 2018).

These practices are expected to increase bacterial load and diversity and to heavily expose fish products to contamination with pathogenic, spoilage and biogenic amine producing bacteria from different sources during catching and prior to and post processing. However, this diversity is not well understood in dried fish products such as dried anchovy. In a single study, $S$. aureus was found in some dried fish products (Moon, Min, Park, Park \& Yoon, 2017).

Moreover, since fish is exposed to different contamination sources in traditional drying and dried fish products are stored at ambient temperature in many developing countries, high bacterial diversity in dried fish is expected as a result of these conditions. Nevertheless, this diversity has not been explored and elucidated in these products in order to assess their microbial safety and quality.

Histamine levels higher than $5 \mathrm{mg} / 100 \mathrm{~g}$ were found in some dried fish such as dried flying fish (Kung et al., 2015). In addition, histamineproducing bacteria such as Raoultell ornithinolytica, Pantoea agglomerans, Proteus vulgaris and Enterobacter amnigenus isolated from dried mahi-mahi were found to be capable of producing 1.25-56.2 mg/100 g of histamine (Lin et al., 2014). Besides their association in scombroid food poisoning, biogenic amines can be used to evaluate the hygienic handling and quality of fish. In this regard, histamine can be used to evaluate the quality of dark muscled fish, whereas putrescine and cadaverine are more subjective parameters to evaluate the quality of white muscled fish and other seafood products (Prester, 2011). Moreover, cadaverine and putrescine have been shown to be involved in the formation of nitrosamines, nitrosopiperidine (NPIP), and nitrosopyrrolidine (NPYR), respectively in in-vitro studies and factors such as impure salts and high temperature have been found to enhance nitrosamine formation (Al Bulushi, Poole, Deeth \& Dykes, 2009). Since dried fish are stored at ambient temperature for months before consumption, the stability of biogenic amines during storage needs to be well understood in order to ensure the safety of these products.

Fresh anchovy contains $12.79 \pm 0.53 \%$ lipid (Gencbay \& Turhan, 2016). Fish with this lipids' content is subject to lipid oxidation during processing and storage. Peroxide value is used as a main parameter to assess lipid oxidation (Milijašević, Babić Milijašević, ĐinovićStojanović, Vesković Moračanin \& Slobodan, 2017). Information on the lipid oxidation in dried fish processed and stored traditionally which is required to evaluate the quality and storage stability of the products is also limited.

Therefore, this study aimed to elucidate the effect of ambient storage $\left(23 \pm 2^{\circ} \mathrm{C}, 68 \% \mathrm{RH}\right)$ on bacterial load and diversity, content of biogenic amines and lipid oxidation in order to evaluate the safety, quality and storage stability of tradi- 
tional dried anchovy.

\section{Materials and Methods}

\subsection{Dried anchovies and storage conditions}

Fresh anchovies were caught from the Sea of Oman and the whole ungutted anchovies were dried by spreading on sandy/clay open sites under the sun for 3-5 days at a temperature of approximately $25^{\circ} \mathrm{C}-35^{\circ} \mathrm{C}$. In Arabian Gulf countries such as Oman and UAE, fish are not salted prior to drying. Moreover in traditional practices, the end point of drying, the quality and safety of fresh anchovies are not evaluated. Two storage studies were conducted. For each storage study about $15 \mathrm{~kg}$ of dried anchovy (Encrasicholina punctifer) was purchased from a local processing site in UAE immediately after drying. Dried anchovies were dispensed into $500 \mathrm{~g}$ samples in closed polyethylene bags and stored at ambient temperature $\left(23 \pm 2^{\circ} \mathrm{C}, 68 \%\right.$ $\mathrm{RH})$ for 12 weeks of storage. This temperature was selected because $23 \pm 2^{\circ} \mathrm{C}$ is a common storage temperature for this product in many developing counties. Samples were analyzed at three-week intervals over 12 weeks. At each sampling occasion, three samples of dried anchovies, each weighing $500 \mathrm{~g}$, were used for analyses. Prior to analyses, dried anchovies were aseptically chopped manually and mixed. The same chopped sample was used for all analyses.

\subsection{Bacterial enumeration and identification}

Total aerobic bacteria were enumerated on tryptone soya agar (TSA) (Oxoid, UK), supplemented with $2 \% \mathrm{NaCl}$ (Oxoid, UK) and incubated aerobically at $32{ }^{\circ} \mathrm{C}$ for three days (Al Bulushi, Poole, Deeth \& Dykes, 2008). To recover the injured bacteria of specific groups, a thin agar layer method (TAL) was used in the selective media (Wu, 2008). In this method, Baird-Parker agar and ISO violet red bile glucose agar were overlaid with $6 \mathrm{~mL}$ of TSA before inoculation. Staphylococcu $S$. aureus was enumerated on Baird-Parker agar (Oxoid, UK), supplemented with rabbit plasma fibrinogen (Oxoid, UK) and incubated at $37^{\circ} \mathrm{C}$ for $48 \pm$ 2 h (Reginald \& Gayle, 2016). Staphylococcus aureus production of coagulase as a means of identification was confirmed by the Staphytect plus system (Oxoid, UK). Enterobacteriaceae were enumerated on ISO violet red bile glucose agar (VRBG, Oxoid, UK) and incubated at $37^{\circ} \mathrm{C}$ for $24 \pm 2 \mathrm{~h}$ (ISO, 2004). Histidine decarboxylating bacteria, LDB and ODB were enumerated on HD-medium and plates were incubated aerobically at $30{ }^{\circ} \mathrm{C}$ for two and four days (Yamani \& Untermann, 1985). This medium consisted of $0.5 \%$ tryptone (Oxoid, UK), $0.5 \%$ yeast extract (Oxoid, UK), $2.7 \%$ L-histidine.2HCl (Sigma, Germany), 0.5\% NaCl (Oxoid, UK), 0.1\% $\mathrm{CaCO}_{3}$ (Sigma, Germany), $2 \%$ agar (Oxoid, UK) and $0.006 \%$ bromocresol purple (Sigma, Germany), and the $\mathrm{pH}$ was adjusted to $\mathrm{pH}$ 5.3. For enumeration of LDB and ODB, L-histidine. $2 \mathrm{HCl}$ was replaced by L-lysine monohydrochloride (Sigma, Germany) and Lornithine monohydrochloride (Sigma, Germany) respectively. To facilitate the enumeration of LDB and ODB, $0.01 \%$ pyridoxine hydrochloride (Sigma, USA) was added as a coenzyme (Frank, Baranowski, Chongsiriwatana, Brust \& Premaratne, 1985).

Eighteen isolates were randomly selected using Harrison's disc for randomized colony selection (Harrison 1938, cited by Harrigan, 1998) at each sampling occasion. The isolates were purified twice in TSA, supplemented with $2 \%$ agar and stored on beads (Abtek, UK) at -80 ${ }^{\circ} \mathrm{C}$ until identified. Isolates were identified to the genus and species levels by VITEK 2 compact (bioMérieux, France), using GP and GN cards and software version of 05.02 according to the manufacturer's instructions, and by sequencing of the $16 \mathrm{~S}$ rRNA gene. The 16S rRNA gene of selected strains was amplified by the PCR procedure described by Ayyash et al. (2018). PCR primers 27F (5'-AGAGTTTGATCCTGGCTCAG-3') and 1492R (5'-TACGGYTACCTTGTTACGACTT3') were employed during amplification. PCR mixtures were prepared following the manufacturer's protocol (Qiagen, Cat No./ID: 201443) and subjected to initial denaturation at $94^{\circ} \mathrm{C}$ for $2 \mathrm{~min}$ followed by 35 cycles of 
heating at $94^{\circ} \mathrm{C}(20 \mathrm{sec})$, primer annealing at $53^{\circ} \mathrm{C}(20 \mathrm{sec})$ and extension at $70^{\circ} \mathrm{C}$ for $1.5 \mathrm{~min}$. The final extension was carried out at $70^{\circ} \mathrm{C}$ for $5 \mathrm{~min}$ for 1 cycle. Presence of specific PCR products was confirmed by agarose electrophoresis. The DNA sequence of PCR products was carried out by Macrogen Sequencing Facilities (http://dna.macrogen.com, Seoul, Korea). Sequence results were aligned with the NCBI database using the BLAST algorithm. BLAST and probabilities were carried out by Macrogendna.com. A probability level of $\geq 93 \%$ was considered for bacterial identification by VITEK 2 compact.

\subsection{Determination of water content, water activity, peroxide value and color}

Water content was determined gravimetrically by drying at $105^{\circ} \mathrm{C}$ in an air convection drier (Gallenkamp, UK) to a consistent weight (Association of Official Analytical Chemists, 1990). Water activity was measured by a water activity meter (Rotronic, USA). Peroxide value was measured using a method provided by Egan, Kirk and Sawyer (1981). Briefly, $0.5 \mathrm{~g}$ of dried anchovies was mixed with $25 \mathrm{~mL}$ of a mixed solution (acetic acid (Sigma, Germany): chloroform (Sigma, Germany), 3:2). Then, $1 \mathrm{~mL}$ of saturated potassium iodide (Sigma, Germany) was added and the sample was kept in a dark place for $10 \mathrm{~min}$. A total of $30 \mathrm{~mL}$ of water was added and the liberated iodine was titrated with $0.01 \mathrm{~N}$ sodium thiosulfate (Sigma, Germany) in the presence of $1 \mathrm{~mL}$ of freshly prepared $1 \%$ starch (Sigma, Germany) until the disappearance of the blue color. Peroxide value was calculated as meq/ $\mathrm{kg}$ lipid according to the following formula:

$$
P V=(A-B) / S \times 10
$$

Where, $\mathrm{A}$ is the titration value for the sample, $\mathrm{B}$ is the titration value for the blank, and $\mathrm{S}$ is the weight of the sample.

The color of dried anchovy was measured using a color meter, Minolta Chroma meter (Model CR-310, Japan) and a method followed by Rahman, Al-Amri and Al-Bulushi (2002). Briefly, the equipment was calibrated with a white standard calibration plate provided by the manufacturer. Six dried anchovies were placed on a flat surface, the tip of the measuring head was pointed on the sample and the color measurement was taken. Five readings for each value from each sample were recorded. The results were expressed in Hunter as L, a and b values, where $\mathrm{L}$ is lightness or darkness (black $\mathrm{L}=0$; white $\mathrm{L}=$ 100), a is intensity of red color and b is intensity of yellow color.

\subsection{Determination of amino acids decarboxylation activity}

The abilities of the isolates to decarboxylate histidine, lysine and ornithine were assessed using HD-medium developed by Yamani and Untermann (1985). This medium was composed of $2 \mathrm{~g}$ peptone, $1 \mathrm{~g}$ Lab-lemco powder, $5 \mathrm{~g} \mathrm{NaCl}, 10$ $\mathrm{g}$ L-histidine monohydrochloride monohydrate (Sigma, Germany), $10 \mathrm{~mL}$ bromo-cresol green solution $0.1 \%, 10 \mathrm{~mL}$ chlorophenol red solution $0.2 \%$ and $1000 \mathrm{~mL}$ deionized water. Pyridoxine hydrochloride was added to the medium to facilitate the decarboxylation of lysine and ornithine. Briefly, $100 \mu \mathrm{L}$ aliquot of $24 \mathrm{~h}$ old isolates was inoculated in HD-medium; the medium was immediately sealed with mineral oil and incubated at $32{ }^{\circ} \mathrm{C}$ for 4 days. The presence of amino acid decarboxylase was assessed by changing the color of the medium from green to violet.

\subsection{Determination of biogenic amines}

Whole dried anchovy was ground using a commercial blender (Black and Decker, USA). Ground dried anchovies ( $5 \mathrm{~g}$ ) were homogenized for $2 \mathrm{~min}$ at high speed in a homogenizer (Black and Decker, USA) with $20 \mathrm{~mL}$ chilled $6 \%$ trichloroacetic (TCA) (Sigma, USA) in a $50-\mathrm{mL}$ centrifuge tube for $3 \mathrm{~min}$. The homogenates were centrifuged at $10,000 \mathrm{~g}$ for $10 \mathrm{~min}$ at $4{ }^{\circ} \mathrm{C}$ and filtered through Whatman No. 2 filter paper (Sigma, USA). The filtrates were transferred in a 50-mL volumetric flask and brought to a final volume of $50 \mathrm{~mL}$ with TCA. Aliquots $(20 \mathrm{~mL})$ were placed into storage vials and stored at -50 
${ }^{\circ} \mathrm{C}$ until use. Histamine, cadaverine and putrescine contents were determined by HPLC using a Lichrospher100 RP-18 reversed-phase column (5 lm, 125.4.6 mm, E. Merck, Damstadt, Germany). The mobile phase consisted of water and methanol (Sigma, Germany). The gradient elution program was started with 50/50 (methanol : water) at a low rate of $0.8 \mathrm{~mL} / \mathrm{min}$ for $5 \mathrm{~min}$. Then the gradient elution was followed by a linear increase to $85 / 15$ (methanol : water) at the same flow rate for $6.5 \mathrm{~min}$. The latter protocol was held for another $5 \mathrm{~min}$ and then decreased to $50 / 50(0.8 \mathrm{~mL} / \mathrm{min})$ for the last $2 \mathrm{~min}$.

The standards consisted of putrescine dihydrochloride (Put), cadaverine dihydrochloride (Cad) and histamine dihydrochloride (Him) (Sigma, Germany). Put (91.5 mg), Cad (85.7 mg) and Him $(82.8 \mathrm{mg})$ were prepared in $50 \mathrm{~mL}$ of 0.1 $\mathrm{M} \mathrm{HCl}$ and used as the standard stock solution (each at $1.0 \mathrm{mg} / \mathrm{mL}$ ). Before injection to HPLC, the sample and standards were derivatized and the biogenic amines contents were determined as described by Tsai et al. (2005).

\subsection{Statistical analysis}

Bacterial numbers are reported as $\log _{10} \mathrm{CFU} / \mathrm{g}$. A one-way ANOVA test was used to evaluate the effect of ambient storage on the parameters, whereas Tukey Simultaneous Test was used to evaluate the differences between the initial and final values of each parameter during storage. These tests were conducted in Minitab release 14 software (Minitab Inc., USA), and a level $p$ $<0.05$ was considered statistically significant. Each sample was run in 2-6 replicates.

\section{Results and Discussion}

\subsection{Bacterial counts}

Changes in bacterial counts during ambient storage can be seen in Table 1 . The total aerobic bacterial count of $\log 4.9 \pm 0.85 \mathrm{CFU} / \mathrm{g}$ indicates the good microbial quality of dried anchovies as compared with $\log 5 \mathrm{CFU} / \mathrm{g}$ set for good quality foods (International Commission on Microbiological Specifications for Foods, 1986). This count may also indicate the dominance of meso- philic bacteria in dried anchovies during ambient storage as anchovies are heavily contaminated during handling at ambient temperature. In fact, the dominancy of mesophilic bacteria in dried anchovies prior and during ambient storage should be expected since dried anchovies are handled at ambient temperature and this group grow at ambient temperature with an optimum temperature of $35^{\circ} \mathrm{C}$ (Ray \& Bhunia, 2014). It is expected that the main sources of mesophilic bacteria in dried anchovies are drying surfaces, air born bacteria, human contact and packaging. The practices of traditional catching such as exposure to poor hygienic conditions during catching, handling and drying were expected to heavily increase TAB in dried anchovies, however, the TAB were found to be within the limit of good quality food (International Commission on Microbiological Specifications for Foods, 1986).

It is quite possible that traditional drying times e.g. 5 days and direct sunlight either killed some bacteria or caused cell injury to others. Moreover, the water activity of about 0.5 (Table 2) was another inhibitory factor to limit bacterial growth to $\log 4.9 \pm 0.85 \mathrm{CFU} / \mathrm{g}$. Total aerobic bacterial count in our study was lower than the $\log 8 \mathrm{CFU} / \mathrm{g}$ found in some dried fish (Jakhar, Kumar \& Vardia, 2015). This discrepancy may reflect the effect of fish environment and hygienic handling status on the bacterial load of dried fish. Anchovies which were used in this study were harvested from the sea whereas those used in that study (Jakhar et al., 2015) were harvested from fresh water. These environments have different microbial flora which can be a source of microbial flora in fish besides handling ( $\mathrm{Al} \mathrm{Bu}-$ lushi et al., 2009). Total aerobic bacteria counts did not significantly change $(p>0.05)$ during ambient storage for 12 weeks. This trend can be expected as water activity (Table 2) did not exceed 0.5 during storage which is an inhibitory value for bacterial growth.

Dried anchovies were initially loaded with $\log$ $3.7 \pm 0.57 \mathrm{CFU} / \mathrm{g}$ and $4.2 \pm 0.05 \mathrm{CFU} / \mathrm{g}$ of $S$. aureus and Enterobacteriaceae respectively. The $S$. aureus count in the current study was higher than that found in some dried fish (Kakati, Sharma \& Goswami, 2017). However, this count is not expected to create any safety risk factor as a typical count of $10^{5}$ - 
Table 1: Bacterial counts in dried anchovies during storage at $23 \pm 2^{\circ} \mathrm{C}, 68 \% \mathrm{RH}$

\begin{tabular}{|c|c|c|c|c|c|c|}
\hline \multicolumn{7}{|c|}{ Bacterial count, $\log _{10} \mathrm{CFU} / \mathrm{g}$} \\
\hline Time, week & TAB & S. aureus & ENT & HDB & LDB & ODB \\
\hline 0 & $4.9 \pm 0.85^{a}$ & $3.7 \pm 0.57^{a}$ & $4.2 \pm 0.05^{a}$ & $3.7 \pm 0.72^{a}$ & $3.9 \pm 0.40^{a}$ & $4.1 \pm 0.24^{a}$ \\
\hline 3 & $4.5 \pm 0.80^{a}$ & $3.5 \pm 0.34^{a}$ & $3.1 \pm 1.1^{a}$ & $2.7 \pm 0.73^{a}$ & $3.7 \pm 0.31^{a}$ & $3.5 \pm 0.02^{a}$ \\
\hline 6 & $4.6 \pm 0.92^{a}$ & $3.9 \pm 0.27^{a}$ & $3.2 \pm 0.49^{a}$ & $3.0 \pm 0.22^{a}$ & $4.2 \pm 0.40^{a}$ & $4.0 \pm 0.85^{a}$ \\
\hline 9 & $4.1 \pm 1.5^{a}$ & $3.7 \pm 0.23^{a}$ & $3.3 \pm 0.49^{a}$ & $3.8 \pm 0.65^{a}$ & $4.7 \pm 0.04^{a}$ & $4.7 \pm 0.15^{a}$ \\
\hline 12 & $4.8 \pm 0.51^{a}$ & $4.0 \pm 0.04^{a}$ & $3.2 \pm 0.16^{a}$ & $3.8 \pm 0.38^{a}$ & $3.9 \pm 0.69^{a}$ & $4.0 \pm 0.40^{a}$ \\
\hline
\end{tabular}

Each mean was compared with that at week 0 . Means with different alphabetical superscripts in the same column are significantly different $(p<0.05), \mathrm{n}=3$

TAB: total aerobic bacteria, EN: Enterobacteriaceae, HDB: histidine decarboxylating

LDB: lysine decarboxylating bacteria, ODB: ornithine decarboxylating bacteria

Table 2: Water content, water activity and biogenic amines contents in dried anchovies during storage at $23 \pm 2^{\circ} \mathrm{C}, 68 \% \mathrm{RH}$

\begin{tabular}{lllllll}
\hline $\begin{array}{l}\text { Time, } \\
\text { week }\end{array}$ & \% water & $\mathrm{a}_{w}$ & $\begin{array}{l}\mathrm{PV}, \\
\mathrm{meq} / \mathrm{kg}\end{array}$ & $\begin{array}{l}\text { His, } \\
\mathrm{mg} / \mathrm{kg}\end{array}$ & $\begin{array}{l}\mathrm{Cad}, \\
\mathrm{mg} / \mathrm{kg}\end{array}$ & $\begin{array}{l}\text { Put, } \\
\mathrm{mg} / \mathrm{kg}\end{array}$ \\
\hline 0 & $8.3 \pm 0.03^{a}$ & $0.48 \pm 0.00^{a}$ & $0.19 \pm 0.02^{a}$ & $5.252 \pm 4.3^{a}$ & $8.585 \pm 1.9^{a}$ & $5.858 \pm 0.6^{a}$ \\
3 & $8.3 \pm 0.04^{a}$ & $0.48 \pm 0.00^{a}$ & $0.34 \pm 0.15^{a}$ & $8.282 \pm 5.5^{a}$ & $5.656 \pm 0.75^{a}$ & $5.252 \pm 0.5^{a}$ \\
6 & $8.5 \pm 0.43^{a}$ & $0.49 \pm 0.00^{b}$ & $0.28 \pm 0.12^{a}$ & $3.838 \pm 2.6^{a}$ & $7.676 \pm 4.0^{a}$ & $9.090 \pm 3.5^{a}$ \\
9 & $7.9 \pm 0.34^{a}$ & $0.50 \pm 0.00^{b}$ & $0.20 \pm 0.01^{a}$ & $2.424 \pm 0.84^{a}$ & $6.666 \pm 1.3^{a}$ & $5.656 \pm 1.3^{a}$ \\
12 & $9.1 \pm 0.14^{b}$ & $0.51 \pm 0.00^{b}$ & $0.30 \pm 0.11^{a}$ & $5.656 \pm 3.8^{a}$ & $3.838 \pm 1.0^{a}$ & $3.838 \pm 00^{a}$ \\
\hline
\end{tabular}

Each mean was compared that at week 0. Means with different alphabetical superscripts in the same column are significantly different $(p<0.05), \mathrm{n}=2-6$

PV: peroxide value, His: histamine, Cad: cadaverine, Put: putrescine

$10^{8} \mathrm{CFU} / \mathrm{g}$ of $S$. aureus is required for enterotoxin production and secondly, the enterotoxins production requires a water activity level of 0.85-1.0 which was not provided by dried anchovies in the current study (Montville \& Matthews, 2008; Stewart, 2003). The Enterobacteriaceae load indicated that the product had been exposed to cross-contamination of sanitary sources, especially from feces of animals. In fact, as per traditional processing, anchovies are processed in open sites where different animals have access to the products during processing. Although most Enterobacteriaceae are heat-sensitive (Baylis, Uyttendaele, Joosten \& Davies, 2011), the presence of these microorganisms in anchovies indicates that traditional drying temperature and time did not destroy Enterobacteriaceae totally and dried anchovies served as a vehicle for this group of microorganisms. The common Enterobacteriaceae sanitary sourced pathogens such as Salmonella sp. and E. coli which are expected to be among the flora due to contamination from humans during handling were not found among the Enteriobacteriacea in the current study. This absence may be attributable to the effect of the drying temperature. In fact, the counts of some Enteriobacteriacea, such as Salmonella sp. and Salmonella typhimurium, were found to decrease during drying (Ingham, Searls \& Buege, 2006).

During ambient storage for 12 weeks, neither $S$. aureus nor Enterobacteriaceae showed statistic- 
244 | Al Bulushi et al.

Table 3: Bacterial diversity in dried anchovies during storage at $23 \pm 2^{\circ} \mathrm{C}, 68 \% \mathrm{RH}$

\begin{tabular}{|c|c|c|c|c|c|c|c|}
\hline \multirow[t]{2}{*}{ Bacteria } & \multirow[t]{2}{*}{ AC/Bio \# } & \multicolumn{5}{|c|}{ Storage, week } & \multirow[t]{2}{*}{$\#$} \\
\hline & & 0 & 3 & 6 & 9 & 12 & \\
\hline Macrococcus sp. & KP181835.1 & 1 & & & & & 1 \\
\hline Psychrobacter sp. & FJ984919.1 & 2 & 1 & 1 & 2 & & 6 \\
\hline Staphylococcus sciuri & KT955004.1 & 3 & & & & 4 & 7 \\
\hline Staphylococcus aureus* & & 13 & 10 & 15 & 11 & 5 & 54 \\
\hline Pseudomonas fluorescens & 5000001100101240 & 3 & & & & & 3 \\
\hline Alloiococcus otitis & 000002000000000 & 5 & 6 & & 3 & 10 & 24 \\
\hline Aeromonas salmonicida & 0000000000000200 & 2 & & & & 1 & 3 \\
\hline Kocurica kristinae & 04000203220031 & 10 & 1 & 1 & & 2 & 14 \\
\hline Acinetobacter lwoffii & 0000000100000000 & 5 & 15 & 11 & 3 & 10 & 44 \\
\hline Serratia fonticola & 616363563561101 & 1 & & & & & 1 \\
\hline Staphylococcus xylosus & 430046057773231 & 6 & 4 & & & & 10 \\
\hline Micrococcus luteus & 041032301000000 & 1 & & & & & 1 \\
\hline Staphylococcus warneri & 050002003220231 & 2 & 5 & 1 & 10 & 19 & 37 \\
\hline Streptococcus alactolyticus & 000030310270021 & 1 & & & & & 1 \\
\hline Staphylococcus saprophyticus & 050002012670231 & 1 & & & & 1 & 2 \\
\hline Sphingomonas paucimobilis & 0001200150300210 & 1 & 4 & & & 3 & 8 \\
\hline Staphylococcus hominis & 000000000320231 & & 2 & & 1 & & 3 \\
\hline Staphylococcus gallinarum & 430446056373331 & & 1 & & & & 1 \\
\hline Comamonas testosteroni & 0000000100500001 & & 1 & & & & 1 \\
\hline Aerococcus viridans & 020103000042031 & & 1 & & & & 1 \\
\hline Staphylococcus epidermidis & KP236244.1 & & 1 & 1 & & & 2 \\
\hline Arthrobacter sp. & JX047437.1 & & 1 & & & 1 & 2 \\
\hline Psychrobacter celer & KR051247.1 & & & 5 & & 1 & 6 \\
\hline Pseudomonas oryzihabitans & 4001600140100210 & & & 1 & & & 1 \\
\hline Kocuria rosea & 010010300000000 & & & & 1 & 2 & 3 \\
\hline Staphylococcus caprae & 010002002461221 & & & & 1 & & 1 \\
\hline Sporosarcina aquimarina & КТ922020.1 & & & & 1 & & 1 \\
\hline Desemzia incerta & LN867201.1 & & & & & 1 & 1 \\
\hline Methylobacterium sp. & 0000000200000000 & & & & & 1 & 1 \\
\hline Granulicatella elegans & 010030300000000 & & & & & 1 & 1 \\
\hline Pantoea sp. & AY659872.1 & & & & & 1 & 1 \\
\hline Bhargavaea indica & KT008289.1 & & & & & 1 & 1 \\
\hline Total & & & & & & & 243 \\
\hline
\end{tabular}

$\mathrm{AC}$ : Accession number for sequencing of $16 \mathrm{~S}$ rRNA gene

BIO : Bionumber in VITEK 2 compact

*: Identified by Staphytect plus system 
ally significant change $(p>0.05)$. This trend was attributed to the low water activity of the product of around 0.5 whereas the minimum water activities required for the growth of $S$. aureus and Enterobacteriaceae are 0.8 and 0.94 respectively (Baylis et al., 2011). S. aureus viability in the current study agreed with Moon et al. (2017) who found a significant reduction in $S$. aureus only after 5 months of storage at $24^{\circ} \mathrm{C}$.

The counts of HDB, LDB and ODB ranged from $\log 3.7 \pm 0.72 \mathrm{CFU} / \mathrm{g}, \log 3.9 \pm 0.40 \mathrm{CFU} / \mathrm{g}$ and $\log 4.1 \pm 0.24 \mathrm{CFU} / \mathrm{g}$ at the beginning of storage to $\log 3.8 \pm 0.38 \mathrm{CFU} / \mathrm{g}, \log 3.9 \pm 0.69$ $\mathrm{CFU} / \mathrm{g}$ and $\log 4.0 \pm 0.40 \mathrm{CFU} / \mathrm{g}$ at the end of storage respectively; these changes were not statistically significant $(p>0.05)$. The counts of HDB, LDB and ODB may indicate the potential of these flora to produce histamine, cadaverine and putrescine in fresh anchovies prior to drying.

\subsection{Bacterial diversity}

In total, 243 isolates were identified (Table 3). Twenty-seven species belonging to 20 genera were found, where the Staphylococcus genus was dominant with $49 \%$ of total bacteria, followed by the Acinetobacter genus with $18 \%$ of total bacteria. Throughout the storage, S. aureus, Acinetobacter lwoffii and S. warneri dominated the bacterial flora with $22 \%, 18 \%$ and $15 \%$ of total bacteria respectively. $S$. aureus was the dominant species within the Staphylococcus genus with $45 \%$ followed by $S$. warneri with $31 \%$. Most of bacteria maintained their viability during ambient storage, indicating high diversity of bacteria in dried anchovy. In general, the incidences of Gram-positive bacteria in dried anchovy were higher than those of Gram-negative bacteria. To our knowledge, this study is the first to report the incidences of some bacteria such as Psychrobacter celer, Desemzia incerta, Granulicatella elegans and Bhargavaea indica in dried fish. High bacterial diversity and incidences in dried anchovies could be attributed to high exposure to cross-contamination, mainly from sand and humans during handling and processing. In fact, high $S$. aureus and Alloiococcus otitis incidence indicates high cross-contamination from hu- mans (El-Jakee et al., 2008). Incidence and viability of $S$. aureus in dried anchovy in the current study coincided with that found in some dried fish (Moon et al., 2017).

Maintaining viability in dried anchovy confirmed the earlier finding that $S$. aureus resists drying (Beardpegler, Stubbs \& Vickery, 1988). $S$. aureus enterotoxins have not been assessed in the current study, however, their presence in dried fish has not been reported in other studies to our knowledge. S. warneri, found at high levels in the current study has been reported in various marine fish (Musharrafieh, Tacchi, Trujeque, LaPatra \& Salinas, 2014). Its viability during the storage of dried product indicates its resistance to drying conditions. Among the Gram-negative bacteria, A. lwoffi dominated the flora. This infectious bacterium, which originates from humans, was found to resist the drying conditions; this could explain its viability and dominance in the current study (Jawad, Heritage, Snelling, GascoyneBinzi \& Hawkey, 1996).

Among biogenic amines producing flora, HDB mainly dominated the flora by $15 \%$ followed by LDB and ODB by $9 \%$ (each) (Table 4). S. warneri showed the highest incidence of decarboxylation of histidine followed by decarboxylation of lysine and ornithine. S. warneri strains' abilities to decarboxylate histidine, lysine and ornithine in the current study agreed with Marino, Frigo, Bartolomeoli and Maifreni (2011) who found that 9 of 14 S. warneri strains decarboxylated histidine, lysine and ornithine. In fact, Staphylococcus sp. have been widely shown to have amino acid decarboxylation activities, mainly of histidine, lysine, ornithine and tyrosine; the main Staphylococcus sp. which showed decarboxylation activity of these amino acids include S. xylosus, S. pasteuri, S. aureus, S. sciuri, S. warneri, and S. vitulinus (Marino et al., 2011). Despite this potential, Staphylococcus sp. were found to be weaker formers of biogenic amines than certain Gram-negative species such as Morganella morganii (Rodriguez-Jerez, MoraVentura, López-Sabater \& Hernandez-Herrero, 1994). Moreover, the reasonably low biogenic amine contents in the current study could indicate that these biogenic amines had been formed mainly by weaker producers of biogenic amines such as Staphylococcus sp. 
$246 \mid$ Al Bulushi et al.

Table 4: Amino acid decarboxylation potentials of the bacterial flora of dried anchovies

\begin{tabular}{llll}
\hline Bacteria & HD & LD & OD \\
\hline Staphylococcus xylosus (10) & 6 & & 2 \\
Micrococcus luteus (1) & 1 & & \\
Staphylococcus warneri (37) & 15 & 2 & 1 \\
Streptococcus alactolyticus (1) & 1 & & \\
Staphylococcus saprophyticus (1) & 1 & & 1 \\
Kocurica kristinae (14) & 3 & 2 & 2 \\
Sphingomonas paucimobilis (8) & 6 & 1 & \\
Staphylococcus caprae (1) & 1 & & \\
Staphylococcus hominis (3) & 1 & & \\
Desemzia incerta (1) & 1 & & \\
Sporosarcina aquimarina (1) & 1 & & \\
Alloiococcus otitis (24) & & 7 & 11 \\
Acinetobacter lwoffi (44) & & 5 & 3 \\
Arthrobacter sp (2) & & 1 & \\
Psychrobacter celer (6) & & 1 & 1 \\
Psychrobacter sp.(6) & & 1 & \\
Bhargavaea indica (1) & & 1 & \\
Aeromonas salmonicida (3) & & 1 & \\
Pseudomonas oryzihabitans (1) & & & 1 \\
Total & 37 & 22 & 22 \\
\hline
\end{tabular}

HD: histidne decarboxylation;

LD: lysine decarboxylation;

OD: ornithine decarboxylation

Table 5: Color values in dried anchovies during storage at $23 \pm 2^{\circ} \mathrm{C}, 68 \% \mathrm{RH}$

\begin{tabular}{llll}
\hline Time, week & L value & a value & b value \\
\hline 0 & $47.2 \pm 1.2^{a}$ & $0.90 \pm 0.11^{a}$ & $6.2 \pm 0.25^{a}$ \\
3 & $55.2 \pm 2.8^{b}$ & $1.1 \pm 0.77^{a}$ & $6.9 \pm 0.22^{a}$ \\
6 & $39.0 \pm 0.60^{b}$ & $1.0 \pm 0.19^{a}$ & $6.5 \pm 0.27^{a}$ \\
9 & $37.4 \pm 0.50^{b}$ & $0.88 \pm 0.24^{a}$ & $6.6 \pm 0.46^{a}$ \\
12 & $35.7 \pm 1.9^{b}$ & $1.2 \pm 0.49^{a}$ & $6.6 \pm 0.24^{a}$ \\
\hline
\end{tabular}

Each mean was compared with that of 0 week.

Means with different alphabetical superscripts in the

same column are significantly different $(p<0.05), \mathrm{n}=6$

IJFS | April 2020 | Volume 9 | pages 238-250 


\subsection{Lipid changes}

Peroxide value (PV), an indicator of lipid oxidation, was $0.19 \pm 0.02 \mathrm{meq} / \mathrm{kg}$ at the beginning of storage and it did not significantly increase $(p>0.05)$ to $0.30 \pm 0.11 \mathrm{meq} / \mathrm{kg}$ during ambient storage for 12 weeks. Peroxide values in the current study are not expected to induce any rancidity which is only noticeable at a PV of more than $10 \mathrm{meq} / \mathrm{kg}$ (Egan et al., 1981). Anchovy is a pelagic fatty fish which could be subjected to lipid oxidation, however, the low PV value in the current study indicated good dried anchovy's stability during 12 weeks of storage. The low PV value in the current study could be attributed to the effect of the high direct sundrying temperature and ambient storage. The effect of processing temperature on the stability of lipids was reported by Ortiz et al. (2013) who found that drying at $60^{\circ} \mathrm{C}$ resulted in the formation of more lipid oxidation products than drying at $40^{\circ} \mathrm{C}$. Whereas, the effect of ambient storage temperature was studied by Takiguchi (1996) who found that pulverized niboshi (boiled and dried anchovy) showed a decrease in PV during storage at $25^{\circ} \mathrm{C}$ for 60 days compared with storage at $-20^{\circ} \mathrm{C}$.

The PV value of the dried anchovy in the current study was lower than that found in some dried fish which might be explained by effects of some factors such as fish species, handling and conditions of traditional drying (Kakati et al., 2017). Lipids' stability in dried stored anchovies in the current study agreed with that found in Stolephorus commersonnii which was handled, dried and stored at similar conditions of dried anchovies (Patterson, Kailasam, Giftson \& Immaculate, 2018). The color value of b (yellowness) has been found to increase with lipid oxidation via the interaction of oxidized products with amines in proteins (Thanonkaew, Benjakul, Visessanguan \& Decker, 2006). In the current study, however, neither PV nor b value showed a significant change (Table 5).

\subsection{Biogenic amines changes}

The contents of histamine, cadaverine and putrescine in dried anchovies (Table 2) ranged from
$52 \pm 4.3,85 \pm 1.9$ and $58 \pm 0.6 \mathrm{mg} / \mathrm{kg}$ at the beginning of storage to $56 \pm 3.8,38 \pm 1.0$ and 38 $\pm 0 \mathrm{mg} / \mathrm{kg}$ at the end of storage; these changes were statistically non-significant $(p>0.05)$. In general, histamine levels in dried anchovy in our study did not exceed the FAO/WHO allowed limit for histamine of $200 \mathrm{mg} / \mathrm{kg}$ (Food and Agriculture Organization, 2012).

The contents of all biogenic amines in dried anchovy in the current study were found to be lower than those found in dried fish products such as flying fish, mahi-mahi and anchovy (Kung et al., 2015; Lin et al., 2014). This discrepancy may be attributable to different pre-drying conditions such as handling temperature and hygiene, to the different abilities of contaminating microbial flora to form biogenic amines and to different post-drying properties of the product such as water activity. The effects of these factors have been clearly elucidated in many studies (Kung et al., 2015; Lin et al., 2014). For instance, histamine reached $50 \mathrm{ppm}$ in more than $12 \mathrm{~h}$ during on-board handling of mahi-mahi at $26^{\circ} \mathrm{C}$, whereas, this level was attained within $9 \mathrm{~h}$ at $35^{\circ} \mathrm{C}$ (Staruszkiewicz et al., 2004). Certain bacteria such as Enterobacter aerogenes were found to produce more than 500 ppm histamine in trypticase soy broth supplemented with $1.0 \%$ Lhistidine (Kung et al., 2015). All biogenic amines were stable during the 12-week ambient storage. This stability could be expected as the biogenic amine producers were inactive in the current study due to low water activity in dried anchovies. The stability of the biogenic amines in the current study is in agreement with that reported by Hwang et al. (2012).

\section{Conclusions}

This is the first study to show a high bacterial diversity in a dried fish product such as dried anchovy with 27 species belonging to 20 different genera with the dominancy of Staphylococcus aureus, A. lwoffii and S. warneri. Ambient storage $\left(23 \pm 2^{\circ} \mathrm{C}, 68 \% \mathrm{RH}\right)$ for 12 weeks did not affect the bacterial load, levels of biogenic amines or PV. Traditional dried anchovy was found to be safe microbiologically and to retain good quality for 12 weeks at ambient temperature. The viab-

IJFS | April 2020 | Volume 9 | pages 238-250 
ility and absence of pathogens and good storage stability of traditional anchovies at ambient temperature can make this product a reliable source of animal proteins especially in poor developing countries lacking access to electricity and sea.

\section{Acknowledgements}

This project was funded by Sultan Qaboos University Internal Grand number: IG / AGR / FOOD / $11 / 03$.

\section{References}

Al Bulushi, I. M., Poole, S., Deeth, H. C. \& Dykes, G. A. (2008). Quantitative assessment of total and gram-positive aerobic bacteria in fresh and ambient-temperaturestored sub-tropical marine fish. World Journal of Microbiology $\&$ Biotechnology, 24 (9), 1867-1875. doi:10.1007/s11274-0089687-5

Al Bulushi, I., Poole, S., Deeth, H. \& Dykes, G. A. (2009). Biogenic amines in fish: Roles in intoxication, spoilage, and nitrosamine formation - a review. Critical Reviews in Food Science and Nutrition, 49, 369-77. doi:10.1080/10408390802067514

Association of Official Analytical Chemists. (1990). Official Methods of Analysis of the Association of Chemists. Analysis of the Association of Chemists, Washington, DC., 223-225, 992-995.

Ayyash, M., Abushelaibi, A., Al-Mahadin, S., Enan, M., El-Tarabily, K. \& Shah, N. (2018). In-vitro investigation into probiotic characterisation of streptococcus and enterococcus isolated from camel milk. $L W T$ Food Science and Technology, 87, 478-487. doi:10.1016/j.lwt.2017.09.019

Baylis, C., Uyttendaele, M., Joosten, H. \& Davies, A. (2011). The enterobacteriaceae and their significance to the food industry. ILSI Europe Report Series, 17-28.

Beardpegler, M. A., Stubbs, E. \& Vickery, A. M. (1988). Observations on the resistance to drying of staphylococcal strains. Journal of Medical Microbiology, 26(4), 251-255. doi:10.1099/00222615-26-4-251
Egan, H., Kirk, R. S. \& Sawyer, R. (1981). Pearson's chemical analysis of foods. churchill livingstone. Edinburgh/London/Melbourne/New York.

Food and Agriculture Organization. (2012). Joint fao/who expert meeting on the public health risks of histamine and other biogenic amines from fish and fishery products. Retrieved from www . fao. org / state - of fisheries-aquaculture

Food and Agriculture Organization. (2018). The state of world fisheries and aquaculture. Retrieved from www.fao.org/fileadmin / user_upload / agns / news . . . / Histamine_ Final_Report.pdf

Frank, H. A., Baranowski, J. D., Chongsiriwatana, M., Brust, P. A. \& Premaratne, R. J. (1985). Identification and decarboxylase activities of bacteria isolated from decomposed mahimahi (coryphaenahippurus) after incubation at 0-degrees-c and 32-degrees-c. International Journal of Food Microbiology, 2(6), 331-340. doi:10 . 1016/0168-1605(85)90023-6

Gencbay, G. \& Turhan, S. (2016). Proximate composition and nutritional profile of the black sea anchovy (engraulis encrasicholus) whole fish, fillets, and by-products. Journal of Aquatic Food Product Technology, 25(6), 864-874. doi:10 . $1080 / 10498850$. 2014. 945199

Harrigan, W. F. (1998). Laboratory methods in food microbiology. Gulf Professional Publishing.

Hwang, C.-C., Lin, C.-M., Kung, H.-F., Huang, Y.-L., Hwang, D.-F., Su, Y.-C. \& Tsai, Y.-H. (2012). Effect of salt concentrations and drying methods on the quality and formation of histamine in dried milkfish (chanos chanos). Food Chemistry, 135(2), 839-844. doi:10.1016/j.foodchem.2012.05. 035

Ingham, S. C., Searls, G. \& Buege, D. R. (2006). Inhibition of Salmonella serovars, Escherichia coli O157 : H7 and Listeria monocytogenes during dry-curing and drying of meat: A case study with basturma. Journal of Food Safety, 26(2), 160-172. doi:10 . 1111/j.1745-4565.2006.00040.x 
International Commission on Microbiological Specifications for Foods. (1986). Microorganisms in foods. 2. sampling for microbiological analysis: Principles and specific applications. University of Toronto Press Toronto.

ISO. (2004). Microbiology of food and animal feeding stuffs-horizontal methods for the detection and enumeration of Enterobacteriaceae: Part 2: Colony-count method. Retrieved from https : / / www . iso . org / standard/34566.html

El-Jakee, J., Ata, N., Bakry, M., A. Zouelfakar, S., Elgabry, E. \& A. Gad El-Said, W. (2008). Characteristics of staphylococcus aureus strains isolated from human and animal sources. American-Eurasian J.Agric.and Environ.Sci. 4, 221-229.

Jakhar, J., Kumar, A. \& Vardia, H. K. (2015). Hygenicity and nutritional quality of traditional dried and smoked fishes at kawardha fish market, (chhattisgarh), india, 10991102.

Jawad, A., Heritage, J., Snelling, A. M., GascoyneBinzi, D. M. \& Hawkey, P. M. (1996). Influence of relative humidity and suspending menstrua on survival of acinetobacter spp on dry surfaces. Journal of Clinical Microbiology, 34(12), 28812887.

Kakati, B. K., Sharma, P. \& Goswami, U. C. (2017). Quality evaluation of dried fish products commerce in assam, india. International Journal of Advanced Biological Research, 7(3), 465-469.

Kung, H.-F., Huang, C.-Y., Lin, C.-M., Liaw, L.-H., Lee, Y.-C. \& Tsai, Y.-H. (2015). The histamine content of dried flying fish products in taiwan and the isolation of halotolerant histamine-forming bacteria. Journal of Food and Drug Analysis, 23(2), 335-342. doi:10.1016/j.jfda.2014.10.009

Lin, C.-S., Tsai, H.-C., Lin, C.-M., Huang, C.-Y., Kung, H.-F. \& Tsai, Y.-H. (2014). Histamine content and histamine-forming bacteria in mahi-mahi (coryphaena hippurus) fillets and dried products. Food Control, 42, 165171. doi:10.1016/j.foodcont.2014.02.004

Marino, M., Frigo, F., Bartolomeoli, I. \& Maifreni, M. (2011). Safety-related proper- ties of staphylococci isolated from food and food environments. Journal of Applied Microbiology, 110(2), 550-561. doi:10.1111/j. 1365-2672.2010.04909.x

Milijašević, M., Babić Milijašević, J., ĐinovićStojanović, J., Vesković Moračanin, S. \& Slobodan, L. (2017). Changes of $\mathrm{pH}$ and peroxide value in carp ( cyprinus carpio ) cuts packaged in modified atmosphere. IOP Conference Series: Earth and Environmental Science, 85, 012041. doi:10.1088/ $1755-1315 / 85 / 1 / 012041$

Montville, T. J. \& Matthews, K. R. (2008). Food microbiology: An introduction, 2nd (edn). United States of America: ASM Press, Washington, DC.

Moon, H.-J., Min, K.-J., Park, N.-Y., Park, H.-J. \& Yoon, K.-S. (2017). Survival of staphylococcus aureus in dried fish products as a function of temperature. Food Science and Biotechnology, 26(3), 823-828. doi:10. 1007/s10068-017-0096-0

Musharrafieh, R., Tacchi, L., Trujeque, J., LaPatra, S. \& Salinas, I. (2014). Staphylococcus warneri, a resident skin commensal of rainbow trout (oncorhynchus mykiss) with pathobiont characteristics. Veterinary Microbiology, 169(1-2), 80-88. doi:10. 1016/j.vetmic.2013.12.012

Ortiz, J., Lemus-Mondaca, R., Vega-Galvez, A., Ah-Hen, K., Puente-Diaz, L., Zura-Bravo, L. \& Aubourg, S. (2013). Influence of airdrying temperature on drying kinetics, colour, firmness and biochemical characteristics of atlantic salmon (salmo salar l.) fillets. Food Chemistry, 139(1-4), 162-169. doi:10. 1016/j.foodchem.2013.01.037

Patterson, J., Kailasam, S., Giftson, H. \& Immaculate, J. K. (2018). Effect of drying technologies on the biochemical properties of stolephorus commersonnii. Food Quality and Safety, 2(3), 153-158. doi:10.1093/ fqsafe/fyy010

Prester, L. (2011). Biogenic amines in fish, fish products and shellfish: A review. Food Additives and Contaminants Part A-chemistry Analysis Control Exposure \&6 Risk Assessment, 28(11), 1547-1560. doi:10.1080/19440049.2011.600728 
Rahman, M. S., Al-Amri, O. S. \& Al-Bulushi, I. M. (2002). Pores and physico-chemical characteristics of dried tuna produced by different methods of drying. Journal of Food Engineering, 53(4), 301-313.

Ray, B. \& Bhunia, A. (2014). Fundamental food microbiology. crc press. Boca Raton, Florida $p p, 66$.

Reginald, W. B. \& Gayle, A. L. (2016). FDA/BAM: Staphylococcus aureus. Bacteriological Analytical Manual, Chapter 12. Retrieved from https://www.fda.gov / food / laboratory - methods - food / bam staphylococcus-aureus

Rodriguez-Jerez, J. J., Mora-Ventura, M., LópezSabater, E. \& Hernandez-Herrero, M. M. (1994). Histidine, lysine and ornithine decarboxylase bacteria in spanish salted semipreserved anchovies. Journal of Food Protection, 57, 784-787. doi:10.4315/0362028X-57.9.784

Staruszkiewicz, W. F., Barnett, J. D., Rogers, P. L., Benner, R. A., Wong, L. L. \& Cook, J. (2004). Effects of on-board and dockside handling on the formation of biogenic amines in mahimahi (coryphaena hippurus), skipjack tuna (katsuwonus pelamis), and yellowfin tuna (thunnus albacares). Journal of Food Protection, 67(1), 134-141. doi:10.4315/0362-028X-67.1.134

Stewart, C. M. (2003). Staphylococcus aureus and staphylococcal enterotoxins. Foodborne Microorganisms of Public Health Significance, 359-379.

Takiguchi, A. (1996). Changes in free amino acid composition caused by lipid oxidation in pulverized niboshi (boiled and dried anchovy) during storage. Fisheries Science, 62(2), 240-245. doi:10.2331/fishsci.62.240

Thanonkaew, A., Benjakul, S., Visessanguan, W. \& Decker, E. A. (2006). Development of yellow pigmentation in squid ( loligo peali ) as a result of lipid oxidation. Journal of Agricultural and Food Chemistry, 54, 95662. doi:10.1021/jf052107h

Tsai, Y. H., Kung, H. F., Lee, T. M., Chen, H. C., Chou, S. S., Wei, C. I. \& Hwang, D. F. (2005). Determination of histamine in canned mackerel implicated in a food borne poisoning. Food Control, 16(7), 579585. doi:10.1016/j.foodcont.2004.06.019

Wu, V. C. H. (2008). A review of microbial injury and recovery methods in food. Food Microbiology, 25(6), 735-744. doi:10.1016/j.fm. 2008.04.011

Yamani, M. I. \& Untermann, F. (1985). Development of a histidine-decarboxylase medium and its application to detect other amino-acid decarboxylases. International Journal of Food Microbiology, 2(5), 273278. doi:10.1016/0168-1605(85)90040-6 